but these may be secondary effects. It appears improbable that such small concentrations could be provided reproducibly to the roots of plants growing in soil. Thus, commercially grown tobacco leaf of 'predesigned' alkaloid content does not appear to be feasible by any of the antibiotic applications described in this paper. Department of Agronomy,
University of Maryland, College Park, Maryland.

$$
\text { T. C. Tso }
$$

R. N. JEFFREY

Field Crops Research Branch, ARS, USDA, Beltsville, Maryland.

${ }_{1}$ Grosso, John J., Plant Disease Reporter, 38 (5), 333 (1954).

Heggestad, H. E., and Clayton, E. E., Plant Disease Reporter, 38 (9), 661 (1954).

'Steinegger, E., and Gessler, F., Pharm. Acta Helv., 28, 256 (1954).

- Nickell, L. B., Science News Letter, 67, 14 (April 2, 1955).

${ }^{3}$ McMurtrey, jun., J. E., U.S. Dept. Agric. Tech. Bull., 340 (1933).

\section{A Chemotactic Response in Wheat Bulb Fly Larvæ}

'THE eggs of wheat bulb fly (Leptohylemyia coarctata Fall.) are laid in the soil during the summer and are usually found on fallow land or where there is a light cover of vegetation such as potatoes. The larva develop and remain in the egg in diapause until the following January or February. Meanwhile, such fields may have been autumn-sown with wheat which the larvæ infest upon hatching. The mechanism by which the larvæ locate the wheat plants is the subject of this investigation.

Laboratory observations indicated that cut wheat shoots could be detected in Petri dishes by the larva when both larvæ and shoot were on damp filter paper; but when the shoots were separated from the damp paper by a cover glass laid under them the results were less positive. The use of growing plants was more desirable in tests and the following method was evolved. Wheat seeds were germinated on damp filter paper in Petri dishes and transplanted into a sodium alginate jelly when the first leaf emerged from the coleoptile. Identical dishes of jelly without wheat were made up simultaneously. In preliminary tests, cubes of jelly taken three or four days later from the wheat dish without including or damaging the roots or plants and similar cubes from the nonwheat jelly were placed on damp filter paper around the edge of a Petri dish, and newly hatched, unfed wheat bulb fly larvæ were introduced centrally. A large number of larvæ was later seen in the wheat jelly cubes.

To test this observation, ten Petri dishes were then arranged. The dishes were set up as follows, after minor adjustments in the first five : the jelly was made up to the formula of $1 \mathrm{gm}$. sodium alginate 'Manucol' $S S / L M$ and $0.2 \mathrm{gm}$. calcium citrate to $100 \mathrm{ml}$. of water. In each dish one $\frac{1}{4}$-in. cube of wheat jelly and a similar one of non-wheat jelly were placed opposite and equidistant, $\frac{1}{4}$ in. away from the central fin. square in which ten newly hatched larvæ were introduced. The dishes were orientated differently. The lids were marked out in $\frac{1}{4}$-in. squares and the positions of the larvæ which immediately began to move were recorded on correspondingly squared graph paper every ten minutes.

The larvæ began to aggregate quickly in the wheat jelly, the total number in the various sites after approximately $1 \mathrm{hr}$. being shown in Table 1 .
Table 1. LARVA FOUND IN VARIOUS SITES IN PATRI DISHES con-

\begin{tabular}{|c|c|c|c|c|}
\hline Test & $\begin{array}{c}\text { No. in } \\
\text { wheat jelly }\end{array}$ & $\begin{array}{c}\text { No. in non- } \\
\text { wheat jelly }\end{array}$ & $\begin{array}{c}\text { No. still } \\
\text { wandering }\end{array}$ & Missing \\
\hline 1 & 7 & 2 & 1 & 0 \\
2 & 1 & 0 & 9 & 0 \\
3 & 6 & 1 & 3 & 0 \\
4 & 4 & 1 & 5 & 0 \\
5 & 1 & 1 & 8 & 0 \\
6 & 5 & 0 & 5 & 0 \\
7 & 4 & 1 & 4 & 1 \\
8 & 7 & 0 & 5 & 0 \\
9 & 5 & 0 & 5 & 0 \\
10 & 4 & 1 & 5 & 0 \\
\hline Totals & 44 & 7 & 48 & 1 \\
\hline
\end{tabular}

The total area on which the larvæ could wander (including the sides and top of the cubes) per dish was $12 \cdot 1 \mathrm{sq}$. in. The area of 1 cube (minus base) was 1.25 sq. in. while the proportion of the total area occupied by one cube was $0 \cdot 104$. The number of larvæ which could be expected in an area of cube size per dish would be $1.04 \pm 0.43$ should the wandering be of a random nature; but this is considerably exceeded by the larvæ in the wheat jelly. It is probable that an exudation from the wheat plants into the jelly and thence into the damp filter paper was detected by the larvæ.

The nature of the larval response is still being investigated, as is the constitution of the substance in the wheat jelly. The speed with which a substantial proportion of the larvæ find the jelly (in some experiments 60 per cent reached it within ten minutes) suggests that the response is a directional one (taxis); but the nature and speed of the movement may also be influenced (kinesis) ${ }^{2}$. The larvæ are able to leave the jelly after entering it and when exposed for $24 \mathrm{hr}$. they become dispersed over the dish. It is possible that by this time the substance in the wheat jelly has diffused more or less evenly throughout the dish.

Rothamsted Experimental Station, Barbara M. STOKES

Harpenden, Herts. June 6.

${ }^{1}$ Gemmill, J. F., Proc. Roy. Phys, Soc., Edin., 21, 133 (1927).

${ }^{2}$ Fraenkel, G. S., and Gunn, D. L., "The Orientation of Animals" (Oxford University Press, 1940).'

\section{Inhibitory Effect of Glucose on Enzyme Formation}

THE induced biosynthesis of many microbial enzymes is susceptible to the inhibitory effect of glucose $^{1}$. The physiological significance of this phenomenon has been indicated by the study of an L-histidine-requiring mutant strain of Aerobacter aerogenes in which glucose inhibits the formation of histidase, thereby conserving the L-histidine for its specific role as growth factor ${ }^{2}$. Under conditions that permit a gratuitous, linear production of myoinositol dehydrogenase (another inducible enzyme in $A$. aerogenes) in the absence of the inducing agent, the glucose effect is still operative, indicating that glucose interferes with the production of enzyme rather than with the process of induction ${ }^{3}$.

Recently, it has been possible to demonstrate in two instances the reversal of the glucose inhibition of induced enzyme biosynthesis. In $a_{0}$ wild strain of $A$. aerogenes $\mathrm{x}$-histidine was substituted for ammonium sulphate, the customary nitrogen source of the glucose-containing minimal medium. In a mutant 